\title{
Doing Dirty Work: Listening for Ignorance Among the Ruins of Reflexivity in Music Education Research
}

\author{
Alexis Anja Kallio
}

\begin{abstract}
Recent research in music education has emphasized the importance of reflexive approaches in unsettling the concept of a neutral, objective researcher and critically considered the ways in which cultural others are represented in research texts. Seen to enhance both the rigor and ethical dimensions of research practice, reflexivity has emerged as a hegemonic virtue, highlighting the inherently political aspects of research practice. In this chapter, I interrogate the politics of inquiry involved in reflexive research, considering the ways in which reflexivity may afford the researcher methodological power and hinder relational and responsible work. Reflexivity is thus positioned as a ruin: perpetually reaffirming the benevolence of the already-privileged researcher while doing little to disrupt the structures that keep such privileges at the center of academic practice. However, rather than abandoning such practices altogether, I suggest that reflexivity might be better considered as a way to listen for ignorance and direct attention toward ontological or epistemological difference. In this way, reflexivity serves as an invitation to engage in the politics of diversity through the transformation of researchers themselves.
\end{abstract}

Keywords Ignorance - Music education · Political listening · Qualitative inquiry · Reflexivity $\cdot$ Research ethics $\cdot$ Research methods

\footnotetext{
A. A. Kallio (凶)

Queensland Conservatorium, Griffith University, Brisbane, QLD, Australia

e-mail: alexis.kallio@griffith.edu.au
} 


\section{Introduction}

Educational research not only has a long history of speaking of and speaking for cultural Others but also of projects that endeavor to "civilize" or "include" by transforming those who do not fit into the norms or values of the "mainstream" (Patel 2016). In music education, although multicultural and intercultural work has highlighted the importance of representing and engaging with cultural difference as part of school and university curricula, the research methods that have been employed in coming to know cultural Others have largely remained within the onto-epistemological frameworks of White Western academia. Accordingly, the processes by which cultural Others are included in music education may simultaneously serve to delimit, categorize, rank, govern, and possess them (Simpson 2007; Westerlund and Karlsen 2017). In recent years, reflexivity has been raised as an important response to such concerns, particularly for non-Indigenous, non-racialized, cisgendered, heterosexual, able-bodied, and in other ways privileged scholars seeking to position music education as a transformative practice for social justice (e.g., Hess 2018; Kallio and Länsman 2018; Lind and McKoy 2016; Trulsson and Burnard 2016). Yet, if such reflexivity also takes place within the confines of already-privileged onto-epistemologies and is limited to introspection of - and by the researcher self, it may be asked whether such research approaches are able to dismantle inequitable power structures or whether such "methodological selfabsorption" merely serves to alleviate White researcher guilt (Patai 1994, p. 69). In her seminal (1999) work, Decolonizing Methodologies Linda Tuhiwai Smith noted that the term "research" itself is "one of the dirtiest words in the indigenous world's vocabulary" (p. 1). The question is thus posed: despite all of our reflexive, ethical intentions, are we (still) doing dirty work?

In this chapter, I interrogate the politics of inquiry in music education, particularly attending to the demand of reflexivity in research concerning music education and social justice that often involves individuals and/or social groups who are marginalized or excluded from mainstream music education systems. Following a conceptualization of reflexivity in qualitative research and a brief outline of how it has been pursued in recent music education scholarship, I consider the politics of engagement involved in this reflexive work. Through critically considering some of the ways in which reflexivity may afford the already-privileged researcher methodological power (Pillow 2003), I explore the failures of reflexive approaches in assisting music education scholars to work relationally in ways that go "against the grain" (Kovach 2015, p. 53). Reflexivity is thus positioned as a ruin: perpetually reaffirming the benevolence of the privileged researcher while doing little to disrupt the structures that keep such privileges at the center of academic practice. Yet, rather than abandon reflexivity altogether, I here follow Patti Lather's (2001) advice that "terms understood as no longer fulfilling their promise do not become useless. On the contrary, their very failures become provisional grounds, and new uses are derived" (p. 478). It is precisely through working the ruins of reflexivity that we may envision alternate relations between researcher and research participants. While 
we might be comfortably complacent doing dirty work, if music education research is to be ethical in its engagements with cultural difference, perhaps it is time to get our own hands dirty in the politics of diversity.

\section{The Reflexive Turn: A Promise of Rigor and Ethics}

In the mid- to late twentieth century, interpretivist approaches (most notably those associated with symbolic interactionism) unsettled the concept of the objective, neutral researcher through insisting that researcher subjectivity imbues the entire research process (Peshkin 1982). Situating the researcher in relation to the field, the research process, the research communication, and the production of knowledge, highlighted the limits of perception and understanding, challenging earlier approaches that afforded the researcher a "god's eye view" (Gergen and Gergen 2000, p. 1026). Accordingly, it was seen as essential that researchers " keep in touch' with the grounds of what they do as an integral element of doing it" (Giddens 1991, p. 36). Reflexivity, broadly defined as a "turning back of the experience of the individual upon [themselves]" (Mead 1934, p. 134) as "a social scientific variety of self-consciousness (Delamont 1991, p. 8), has been seen as one way for researchers to approach "“culture' [as] always relational, an inscription of communicative processes that exist, historically, between subjects in relations of power" (Clifford and Marcus 1986, p. 15). In this way, the "reflexive turn" (Clifford and Marcus 1986; Van Maanen 1988) embraced inquiry as an inherently political and ethical process and found a particularly firm foothold in scholarship relating to "critical theory, standpoint theory, textual deconstruction, and sociologies and anthropologies of knowledge, power, and agency" (Macbeth 2001, p. 36). While the definitions of reflexivity are too many, and too varied, to survey within the confines of this chapter, education scholar Douglas Macbeth (2001) outlines two broad programs of reflexivity that are relevant to contemporary music education research practice: positional reflexivity and textual reflexivity. Positional reflexivity, he explains, "takes up the analysts' (uncertain) position and positioning in the world he or she studies and is often expressed with a vigilance for unseen, privileged, or, worse, exploitative relationships between analyst and the world" (p. 38). In the educational sciences (in addition to fields such as anthropology and ethnomusicology), the explorations of emic/etic perspectives and the complexities of power and hegemonies that accompany expressions of positional reflexivity have become part and parcel of rigorous post-positivist research. As Ball (1990) explains:

[the s]elf conscious engagement with the world... provides the possibility of technical rigor in the ethnographic process. The basis of this rigor is the conscious and deliberate thinking of the social process of engagement in the field with the technical processes of data collection and the decisions that that linking involves. I call that linking reflexivity. (p. 159)

Related to positional reflexivity, textual reflexivity is defined as work that "directly [addresses] the work of writing representations" (Macbeth 2001, p. 41). Through 
turning back and interrogating representations of Others in the communication of research through scientific publications, textual reflexivity aims to disrupt "realist assurances about representation and textual coherence" (Macbeth 2001, p. 43).

\title{
3 Reflexivity as a Hegemonic Virtue of Music Education Research
}

The long-standing dominance of the aesthetic philosophical tradition and positivist research practices in mainstream music education research has meant that reflexivity, or at least explicit calls for reflexive research practices, has been a relative latecomer to the field. As Gouzouasis et al. (2014) have argued:

\begin{abstract}
music education research is generally unreflective in terms of the historical challenges that questioned issues of representation, legitimation, and interpretation in the research process. The field seems unaware or unable to come to terms with the challenges to the very nature of the research project that are at the heart of qualitative research. Assumptions of objectivity and positivism abound with little explication of reflexivity. (p. 17)
\end{abstract}

However, recent decades have witnessed a significant shift in music education, from reflexivity made explicit in research relating to cultural diversity (e.g., Dunbar-Hall 2009; Karlsen 2007; Marsh 2002; Saether 2003) to being positioned as an essential element of inquiry more generally - particularly that which contributes toward social justice in/through music education policy or practice (e.g., Allsup 2017; Bartleet and Higgins 2018; Laes 2017; Miettinen et al. 2018; Nichols 2016). As in the social and education sciences, reflexivity in music education research has been seen as a way to work toward scientific rigor through a more accurate representation of the Other, and toward a more ethical research practice through lessening the power divide between researcher and researched.

Related to the substantial body of ethnomusicological work surrounding concerns of cultural representation and authenticity in multicultural music education practice (e.g., Campbell 2002, 2018; Schippers 2010; Volk 1998), concerns have arisen regarding the accuracy and sensitivity with which we write about cultural Others in music education scholarship. Reflexivity has been seen as one means to bolster the validity of representation, acknowledging the researcher's own positionality/ies as insider, outsider, or occupying a cultural space in between. Trulsson and Burnard (2016) argue that intercultural music education research is "an interpersonal meeting which also involves a meeting of self" (p. 123), as is seen in Dieckmann's (2016) acknowledgement that social constructions of her own "race, national identity, heritage identity and heritage culture" (p. 41) influence the research process. In working toward an accurate, and complete, portrayal of the ethnocultural other, Dieckmann cites Pascale (2011) in emphasizing the importance of acknowledging one's own subjectivities:

Processes of subjectification give researchers access to ways of thinking and writing about categories such as race, gender, sexuality, and ability without reifying them and without 
divesting them of the historical relations of power through which they are produced. Analyses and narratives about who people are, and the lives they have lived, will always be incomplete if we cannot see the processes of social formation through which they become inaugurated as subjects. (p. 154-155)

In this way, reflexivity is worked into inquiry procedures as what Altheide and Johnson (2011) term "validity-as-reflexive-accounting" (p. 585), a means to enhance the accuracy of produced knowledge through "redressing some of the researcher's bias" (Dieckmann 2016, p. 41).

Related to these concerns of accuracy and rigor, the research ethics attended to by reflexive approaches in music education are not those stipulated by institutional review boards or ethics committees but, rather, those that arise relationally during the course of research (Kuntz 2016). These ethics are those that develop in situ, as part of the interactions between those involved in the research process, requiring reassessment as these relationships change and develop. Accordingly, a relational ethical practice:

is created and recreated at each step in the process; ... it is the accumulation of granular decisions to be accountable to the participant, to the community, to academia, and to the reader that ultimately shapes the researcher's ethical orientation and determines the moral arc of a study. (Nichols 2016, p. 450)

Positional reflexivity, as an ethical imperative of socially just research practice, is perhaps most clearly seen through the recent rise in positionality statements in music education research texts. These statements refer to researchers' own racial, ethnic, cultural, or gendered identifications, as well as their musical positionings. For instance, in her article on the ethics of world music participation, Hess (2013) positions herself as a "white Western woman" when describing the challenges that she experiences in reconciling her background as a university vocal major with her interest in Ghanaian drumming. In contrast, Saether (2003) has described her background in Scandinavian folk traditions as an asset in conducting research in the Gambia, with "the way to talk or not to talk - about music or teaching is in many ways similar in these two oral cultures" (p. 70). In this way, recognition of one's own positionings, both cultural and musical, has been seen as one way to recognize and "mitigate power relations" (Bradley 2007, p. 136), bringing the worlds of researchers and research participants into view, moving away from the categorization and classification of Others, toward a more complex, ethical dialogue and interaction as part of the production of knowledge (Westerlund and Karlsen 2017).

Particularly as a follow-up on previous studies, textual reflexivity in music education has provided researchers with opportunities to learn from previous mistakes and to reflect upon the standpoints from which we "look around and draw up what we see" (Allsup 2017, p. 9). While scholars have made attempts to overcome a one-sided approach to ethnography and other research approaches that are reliant on the researcher having "monolithic power over others" (ibid), working relationally as co-researchers often does little to alleviate the "actual dilemmas of [research] practice" (Josselson 2007, p. 538; Laes 2017; Nichols 2016). For instance, Nichols (2016) attends to the ethical dimensions of her earlier representation of Rie, a 
transgender musician, considering the ways in which textual representation is a product of power structures that support "limited dichotomous thinking" about gender and enable the erasure of identity on paper (p. 447). Textual aspects of the research that might otherwise have remained unattended to, such as the use of personal pronouns, are interrogated through a critical collaboration between Nichols and Rie. Similarly, Laes (2017) analyzes the mistakes she felt were made in her study conducted together with a musician labeled in the category of having cognitive disabilities. She argues that it is "not enough that... research participants are considered as experts of their own personal experiences" (p. 144) and that reflexivity ought to "reshape research practices and discourses" (p. 139). Such work often requires researchers to acknowledge their own complicity in the very hierarchies and knowledge systems that they aim to critique (Laes 2017, p. 138; Kallio 2019), requiring them to operate within what Trulsson and Burnard (2016) term "discomfort zones" (p. 123). These zones have been described as research processes involving feelings of "dread, guilt, and shame" (Nichols 2016, p. 442; see also Kallio 2019), yet, this same discomfort is also seen to facilitate "strong connections... with the people with whom we research and work" (Barton 2014, p. 111). Redressing the power dynamics between researcher and research participants, reflexivity has emerged as a hegemonic academic virtue (Lynch 2000) of relational music education research that is essential for advancing both scholarship and practice (e.g., Bartleet and Higgins 2018).

\section{Reflexivity in Ruins}

Although reflexivity is often associated with critical, anti-objectivistic, relational work, it has been suggested that many conceptions and enactments of reflexivity may not afford the radical social reconstruction they promise (Gorski 2008; Lynch 2000). In exploring the potential shortcomings of reflexive work in music education, I draw upon Lather's (2001) characterization of ethnography as ruin, a space in which scholars are repeatedly confronted with "necessary failure" (p. 482) in order to move beyond "wrestling with representation, blurred genres and the ethics of the gaze" (p. 480) and find their way "into post-foundational possibilities" (p. 482). In this way, walking among the ruins of reflexivity, I aim to not only be reminded of what is no longer, or imagine what might yet be, but to also destabilize and possibly change the critical perspective employed in doing reflexive work. In interrupting the romance of reflexivity as a grand narrative of rigorous, ethical research, I look at what grows in between the cracks and crevices, in aiming to work the ruins in new and productive ways. 


\subsection{The Fine Line Between Introspection and Indulgence}

I have often heard the academic idiom that scholars always research the self, and perhaps this is more characteristic of reflexive research approaches than others and perhaps more surprising when working with individuals or social groups with considerably different backgrounds or perspectives to one's own. It also raises questions with regard to what, or who, research is for, and the purpose that reflexive work serves. Writing an article on decolonizing music education research and methodological responsibility (Kallio 2019), I found myself struggling to write my own story as a means for readers to locate me within the descriptions of relational research that followed. In the few paragraphs I assigned to introduce myself in relation to the Indigenous Sámi artists, musicians, scholars, and educators I was working together with, I described the nationality of my family changing almost with each generation, my childhood memories of coloniality and Indigenous activism in White Australia, the vibrant diversity of Hong Kong where I grew up, and the unexpected research journey that had led to me working in Indigenous contexts in Finland. The promises of such reflexive work, making researcher positionality explicit, lay in the contextualization of analyses and findings as "situated knowledge" (Haraway 1991), an acknowledgement of non-neutrality and of engaging in critically aware, collaborative processes. However, if we understand that social reality and individual identity are multiple and always in flux and if I think of the deep learnings and significant unknowings that this research entailed, this selfnarrative seems insufficient and insincere in its cohesion and linearity.

Where the research process was driven by dialogue and discussion, grappling with misunderstandings or discrepancies between interpretations, writing out my own subjectivity in relation to others felt like an attempt to regather the reins, to re-establish myself as "ethnographic authority" (Britzman 1995, p. 229) when such authority had already been relinquished. Such reflexive work, whether engaged in as part of the research process or written as part of research communication, depends upon an assumption that the researcher is able "to know her/his own subjectivity" in the first place, to select which of these subjectivities are reflexivity-relevant to any given research relationship and context, and "to make this subjectivity known to the reader" (Pillow 2003, p. 184; see also Kumsa et al. 2015). Furthermore, it is dependent on "the possibility of taking a detached position from which it is possible to objectify naïve practice" (Lynch 2000, p. 31) - of which, it may be argued, neither music education nor research ever are. My experiences and understandings of coloniality, music, education, national and cultural identity, research, and so on are undoubtedly different to those of the Sámi artists and experts I collaborated with. Who am I to determine which of my identities or experiences came into play over the course of this research? Who am I to make sense of these subjectivities? Who am I to try to convey the significance of these subjectivities divorced from all of the other encounters and experiences of my life? Who is to say that I can even be aware of or distance myself from who I am, if such becomings took place in relation to 
others - of whose worldviews, experiences, and perspectives I am only partially aware of (at best)?

Reflexive work is often restricted to researcher introspection, without considering the politics of knowledge that the researcher is enculturated into and contributes toward. Indigenous scholars have long critiqued academe as "profoundly saturated by colonial... assumptions and practices which define and characterize the conditions of academic and intellectual endeavours" (Kuokkanen 2007, p. 106). If reflexivity remains within one's own onto-epistemological boundaries (and one may ask if it is indeed possible to extend beyond them), such work risks reinforcing epistemic privileges that determine "what counts as theory, whose work is cited, and what tools are deemed necessary to any project" (Pillow 2015, p. 428). Reflexivity, as introspection therefore reverses a foundational sociological premise: that "we no longer have knowledge of the self through relatedness with others, but rather come to know the other only in so far as we know the self" (Webster 2008, p. 67). It may thus be argued that such reflexive work cannot result in more ethical research relationships or a more equitable research process but rather continues to serve as a means to define and confine the Other through the (academic) domestication of difference.

\subsection{Reflexivity as Apologia}

This is not to suggest that introspection is mere navel-gazing, as the feminist slogan of the 1960s reminds us: the personal is political. Confessions of privilege or oppression, or affiliative expressions with oppressed peoples, are oft employed means for music education scholars to recognize the subjectivities from which they speak/write and acknowledge an awareness of the political structures that frame their own research practice. I think here of the ways that scholars have introduced themselves at conferences or in academic texts as the products of settler colonial histories; as White, white-passing, or non-racialized; as cisgendered; as middle class; as first-generation college graduates; as immigrants; or as LGBTQI+. In music education research, these statements have also illustrated the dynamic intersections between such subjectivities and musical training, preferences, skills, and understandings, each of which manifests differently and affords music education researchers different agencies in different contexts and spaces (e.g., Karlsen 2012). This "struggle for accountability" illustrates what feminist poet Adrienne Rich (1994) termed a politics of location. A reflexive and critical engagement with the politics of location allows scholars to "interrogate the historical, political, and social contexts of our knowledge" (Kirsch and Ritchie 1995, p. 10). Without wanting to diminish the important and often courageous strides that many scholars have taken in voicing their own locations and subjectivities, it is also worth asking critical questions such as what is the political project that this reflexive work is working toward? And who benefits? 
Media and Cultural Studies scholar Andrea Smith (2013) posits that reflexive rituals often do little to address the structures that enable inequity in the first place but instead become a source of power themselves through conferring "cultural capital to those who [seem] to be the "most oppressed"" (Smith 2013, p. 263). In other words, reflexivity statements often reflect an understanding that one needs to have first-hand experiences of injustice (and that these experiences ought to illustrate specific forms of injustice, see Lorde 1984 on the hierarchy of oppression) in order to develop the empathy or awareness required to engage in social justice work and function to establish the author as a legitimate or credible (i.e., authentically oppressed) researcher in such contexts. Similarly, the confession of privilege re-centers "the angst of the researcher" (Lather 2001, p. 484), (re)presenting the researcher as positionally pious (Cousin 2010, p. 9). In music education research, this piety - and the cultural capital associated with it - can be achieved through reflexive statements relating to sex, gender, race, class, sexuality, ability, and so on but also through musical affiliations. Whereas Western art music has long been associated with cultural elitism and scholarship, the cultural capital bestowed upon individuals through musical omnivorousness (Dyndahl et al. 2014) can now also be seen in reflexive statements. I need not look far beyond my own work (e.g., Kallio 2015) for biographies that describe a researcher trained in, and devoted to, classical music but yet also belonging to the world of informal musicking through an interest in musics of other cultures and performing regularly in rock bands. As attempts to forge a closeness with those we research with and justify our right to work within certain spaces, reflexivity rituals may not offer opportunities for researchers to work relationally "against the grain" in dismantling the structures that enable privilege and inequity in the first place but rather serve as apologia. In this way, reflexivity "exonerates, redeems, and purifies [the researcher]; it unburdens him of his wrongs, liberates him, and promises him salvation" (Foucault 1976, p. 62).

Consequently, these reflexive processes risk reinforcing the very inequities they intend to dismantle, with the privileged scholar seen as capable of (and requiring) reflexivity, and the "diverse Other" as merely the occasion for it (Smith 2013). Reflexivity, when limited to researcher introspection, marks "the ontological end-game of each exchange" (p. 67) and secures methodological and conceptual power for the researcher alone to define difference according to a "fixed... picture" of identities, cultures, characteristics, and musics (Westerlund and Karlsen 2017, p. 79) and to (re)write the histories and stories of their research participants in relation to themselves. Perhaps particularly when music education researchers so often represent a privileged majority, " $[\mathrm{t}] \mathrm{his}$ is a form of politics that is more than representational" (Simpson 2007, p. 67). 


\section{Reflexivity on the Tree Line}

In exploring the ruins of reflexivity in music education research, I do not intend to argue a case for abandoning these practices altogether but rather to reconsider the critical lens through which much of this work is done. To consider this work conducted in post-foundational times is not to "assume the absence of any ground; what it assumes is the absence of an ultimate ground, since it is only on the basis of such absence that grounds, in the plural, are possible" (Marchart 2007, p. 14). Thus, reflexivity should serve as more than a means to "superior insight, perspicacity or awareness" (Lynch 2000, p. 26), an opportunity for "methodological self-absorption" (Patai 1994, p. 69), or catharsis (Pillow 2003), as each presupposes a truth that silences or domesticates ontological or epistemological difference. Rather, in concluding this chapter, I suggest that reflexivity might be better considered as a way to listen for such other grounds and engage in the politics of diversity in ways that work toward a more equitable and responsible research landscape.

Reflexivity as a form of listening is not to suggest a wholly receptive engagement - listening is different from hearing. Listening also entails more than remaining silent, as political scientist Susan Bickford (1996) has noted, "words that continually fall into dead silence can have no worldly reality and lead to no joint action. This silent refusal, as deliberate not-listening, is clearly a drastic political act" (Bickford 1996, p. 155). Instead, Bickford (1996) describes listening as "a quality of attention inherent in the very practice of deliberation" (p. 25): as a process of political engagement. She adds that "political listening is not primarily a caring or amicable practice... [w] cannot suppose that political actors are sympathetic toward one another in a conflictual context, yet it is precisely the presence of conflict and differences that makes communicative interaction necessary" (Bickford 1996, p. 2, emphasis added). With this in mind, reflexivity, or the failures and discomforts arising through reflexive processes, might better serve as the means to listen in order to locate ignorance. The term "ignorance" here is employed not to denote stupidity, inferiority, or a lack of capacity for knowing but rather a refusal of the hierarchy of knowledge: a refusal of authority. Drawing upon the work of philosopher Jacques Rancière (2010), we may better understand ignorance as an ignorance of inequality. This calls into question the power/knowledge dialectic, where knowledge is not obsolete but only one among many. Thus, reflexivity, as a "commitment to ignorance" (Quinn 2011) can be seen as a search for directions in which we might better listen (and listen better) - as a space in which to verify equality. This listening is inherently discomfortable work, unsettling norms and values, disrupting established hierarchies, and transforming the researcher self in often unpredictable ways. The virtue then does not lie in reflexivity per se but in the ignorances the process might locate and the opportunities for relational learning within such spaces. Such a commitment to ignorance is not one of resignation but one "that is strong and generous, requiring honor and courage" (Quinn 2011, p. 33).

It is important to note that I do not envision the learning generated through reflexivity as a series of ever-expanding ripples denoting the limits of knowing 
amidst unknowing, growing wider and wider as the researcher learns to listen and gains more and more knowledge and understanding. Such a metaphor continues to place the researcher at the center of research practice, suggests a clearly defined point of no return, and reinstates the right of academe to know everything and everyone. Rather, the researcher's path through unknowing might be better illustrated through the metaphor of a tree line - the point at which the forest meets the arctic tundra. Indigenous Sámi joik artist and musician Sofia Jannok (2016) describes the tree line as:

two completely different landscapes, still coming together somewhere or other. This is the world on the tree line. This land was never empty, she was never wild....

[the tree line] is about diversity. The many, many trees are the ones creating the beautiful unity. Many of us live with several mother tongues, cultures, identities. Why isn't the norm shaped as a tree line?...

Here borders are to be crossed.

Here opposites come together, equally worthy of existing.

Here the contrast rises, showing the beauty.

Here the conflicts begin, if I fight the divisions.

Here the eye realizes the perspectives.

Here the yearning finds peace, with one foot on either side.

Here the storm gets its power. ${ }^{1}$

The politics of diversity that emerge from across, or within, or along this tree line can thus be seen as the norm of music education: as contexts characterized by diversities and multiplicities. Inclusion on the tree line cannot require transformation of one side or the other, or a knowing of the other wholly within the onto-epistemological frames of mainstream academe. Indeed, the tree line is not a fixed boundary at all; it is constantly changing, with roots that extend underground to the other side, mosses that grow beyond set borders, ever-changing dances between light and shadow, and leaves that fall where they may. In this way, the tree line is not something that is researcher-centered nor determined, not static or linear, and not something that can only be crossed once (i.e., into knowing). Rather, it is a path that researchers can traverse, admire the view from one side or the other, straddle with a foot on either side, or turn back. It is an invitation to deeply engaged, relational work. Through orienting oneself toward the discomfort that arises through reflexive practice on the tree line, researchers might find new ways to listen as an ongoing process of "learning to stay with the hard questions" (Thompson 2003, p. 92). Conceptualizing reflexivity as a form of listening here serves as an invitation to engage in risky methodological work (Bickford 1996; Kuntz 2016): work that generates newly dynamic and relational engagements with meaning-making and experience that require - above all - the transformation of ourselves.

\footnotetext{
${ }^{1}$ Sofia Jannok's poem is included here with her permission.
} 


\section{References}

Allsup, R. E. (2017). Ifs, ands, and buts: A polyphonic vision of qualitative research in music education. Bulletin of the Council for Research in Music Education, 214, 7-18.

Altheide, D. L., \& Johnson, J. M. (2011). Reflections on interpretive adequacy in qualitative research. In N. Denzin \& Y. S. Lincoln (Eds.), The SAGE handbook of qualitative research (pp. 581-594). Thousand Oaks: SAGE.

Ball, S. (1990). Self-doubt and soft data: Social and technical trajectories in ethnographic fieldwork. Qualitative Studies in Education, 3(2), 157-171.

Bartleet, B. L., \& Higgins, L. (Eds.). (2018). The Oxford handbook of community music. New York: Oxford University Press.

Barton, G. (2014). Ethnography and music education. In K. A. Hartwig (Ed.), Research methodologies in music education. Newcastle upon Tyne: Cambridge Scholars Publishing.

Bickford, S. (1996). The dissonance of democracy: Listening, conflict and citizenship. Ithaca: Cornell University Press.

Bradley, D. (2007). The sounds of silence: Talking race in music education. Action, Theory and Criticism for Music Education, 6(4), 132-162.

Britzman, D. (1995). "The question of belief": Writing poststructural ethnography. International Journal of Qualitative Studies in Education, 8, 239-252.

Campbell, P. S. (2002). Music education in a time of cultural transformation. Music Educators Journal, 89(1), 27-32.

Campbell, P. S. (2018). Music education and diversity: Bridging cultures and communities. New York: Teachers College Press.

Clifford, J., \& Marcus, G. E. (1986). Writing culture: The poetics and politics of ethnography. Berkeley: University of California Press.

Cousin, G. (2010). Positioning positionality: The reflexive turn. In M. Savin-Baden \& C. Howell Major (Eds.), New approaches to qualitative research: Wisdom and uncertainty (pp. 25-34). New York: Routledge.

Delamont, S. (1991). Fieldwork in educational settings: Methods, pitfalls and perspectives. London: Falmer Press.

Dieckmann, S. (2016). Exploring musical acculturation: The musical lives of South Sudanese Australians, Filipino Australians and White Australians in Blacktown. Doctoral dissertation. Sydney Conservatorium of Music, University of Sydney. Australia.

Dunbar-Hall, P. (2009). Studying music, studying the self: Reflections on learning music in Bali. In B. L. Bartleet \& C. Ellis (Eds.), Music autoethnographies: Making autoethnography sing/ making music personal (pp. 153-166). Bowen Hills: Australian Academic Press.

Dyndahl, P., Karlsen, S., Skårberg, O., \& Nielsen, S. G. (2014). Cultural omnivorousness and musical gentrification. An outline of a sociological framework and its applications for music education research. Action, Criticism, and Theory for Music Education, 13(1), 40-69.

Foucault, M. (1976). The history of sexuality: Vol 1. The will to knowledge. London: Penguin Books Ltd.

Gergen, M. M., \& Gergen, K. J. (2000). Qualitative inquiry: Tensions and transformations. In N. Denzin \& Y. S. Lincoln (Eds.), Handbook of qualitative research (2nd ed., pp. 1025-1046). Thousand Oaks: Sage.

Giddens, A. (1991). Modernity and self-identity: Self and society in the late modern age. Cambridge: Polity Press.

Gorski, P. (2008). Good intentions are not enough: A decolonizing intercultural education. Intercultural Education, 19(6), 515-525.

Gouzouasis, P., Bakan, D., Ryu, J., Ballam, H., Murphy, D., Ihnatovych, D., et al. (2014). Where do teachers and learners stand in music education research? A multi-voiced call for a new ethos of music education research. International Journal of Education \& the Arts, 15(15). http://www. ijea.org/v15n15/. Accessed 1 Oct 2019. 
Haraway, D. J. (1991). Simians, cyborgs, and women: The reinvention of nature. New York: Routledge.

Hess, J. (2013). Performing tolerance and curriculum: The politics of self-congratulation, identity formation, and pedagogy in world music education. Philosophy of Music Education Review, 21(1), 66-91.

Hess, J. (2018). Challenging the empire in empir(e)ical research: The question of speaking in music education. Music Education Research, 20(5), 573-590.

Jannok, S. (2016). ORDA [Liner notes]. In ORDA [CD]. Gamlestan Grammofonbolag.

Josselson, R. (2007). The ethical attitude in narrative research: Principles and practicalities. In D. J. Clandinin (Ed.), Handbook of narrative inquiry: Mapping a methodology (pp. 537-566). Thousand Oaks: Sage.

Kallio, A. A. (2015). Navigating (un)popular music in the classroom: Censure and censorship in an inclusive, democratic music education. Doctoral dissertation. Studia Musica 65. Sibelius Academy, University of the Arts Helsinki. Finland.

Kallio, A. A. (2019). Decolonizing music education research and the (im)possibility of methodological responsibility. Research Studies in Music Education, 42(2), 177-191. https://doi.org/10. 1177/1321103X19845690.

Kallio, A. A., \& Länsman, H. (2018). Sámi re-imaginings of equality in/through extracurricular arts education in Finland. International Journal of Education \& The Arts, 19(7). https://doi.org/10. 18113/P8ijea1907.

Karlsen, S. (2007). The music festival as an arena for learning: Festspel i Pite Älvdal and matters of identity. Doctoral dissertation. Luleå Technical University, Sweden.

Karlsen, S. (2012). Multiple repertoires of ways of being and acting in music: Immigrant students' musical agency as an impetus for democracy. Music Education Research, 14(2), 131-148.

Kirsch, G. E., \& Ritchie, J. S. (1995). Beyond the personal: Theorizing a politics of location in composition research. College Composition and Communication, 46(1), 7-29.

Kovach, M. (2015). Emerging from the margins: Indigenous methodologies. In S. Strega \& L. Brown (Eds.), Research as resistance: Revisiting critical, indigenous and anti-oppressive approaches (2nd ed., pp. 43-64). Toronto: Canadian Scholars' Press.

Kumsa, M. K., Chambon, A., Yan, M. C., \& Maiter, S. (2015). Catching the shimmers of the social: From the limits of reflexivity to methodological creativity. Qualitative Research, 15(4), 419-436.

Kuntz, A. (2016). The responsible methodologist: Inquiry, truth-telling, and social justice. New York: Routledge.

Kuokkanen, R. J. (2007). Reshaping the university: Responsibility, indigenous epistemes and the logic of the gift. Vancouver/Toronto: University of British Columbia Press.

Laes, T. (2017). Beyond inclusion: A reflexive narrative of the inclusive potentials of activist scholarship in music education. Bulletin of the Council for Research in Music Education, 210-211, 137-151.

Lather, P. (2001). Ethnography: Of ruins, aporias, and angels. In P. Atkinson, A. Coffey, S. Delamont, J. Lofland, \& L. Lofland (Eds.), Handbook of ethnography (pp. 477-492). London: SAGE.

Lind, V., \& McKoy, C. (2016). Culturally responsive teaching in music education: From understanding to application. New York: Routledge.

Lynch, M. (2000). Against reflexivity as an academic virtue and source of privileged knowledge. Theory, Culture \& Society, 17(3), 26-54.

Macbeth, D. (2001). On "reflexivity" in qualitative research: Two readings, and a third. Qualitative Inquiry, 7(1), 35-68.

Marchart, O. (2007). Post-foundational political thought: Political difference in Nancy, Lefort, Badiou and Laclau. Edinburgh: Edinburgh University Press.

Marsh, K. (2002). Observations on a case study of song transmission and preservation in two Aboriginal communities: Dilemmas of a 'neo-colonialist' in the field. Research Studies in Music Education, 19, 1-10. 
Mead, G. H. (1934). In C. W. Morris (Ed.), Mind, self and society. Chicago: University of Chicago Press.

Miettinen, L., Gluschankof, C., Karlsen, S., \& Westerlund, H. (2018). Initiating mobilizing networks: Mapping intercultural competences in two music teacher programmes in Israel and Finland. Research Studies in Music Education, 40(1), 67-88.

Nichols, J. (2016). Sharing the stage: Ethical dimensions of narrative inquiry in music education. Journal of Research in Music Education, 63(4), 439-454.

Pascale, C. M. (2011). Cartographies of knowledge: Exploring qualitative epistemologies. Thousand Oaks: SAGE.

Patai, D. (1994). (Response) When method becomes power. In A. Gitlen (Ed.), Power and method (pp. 61-73). New York: Routledge.

Patel, L. (2016). Decolonizing educational research: From ownership to answerability. New York/London: Routledge.

Peshkin, A. (1982). The researcher and subjectivity: Reflections on an ethnography of school and community. In G. Spindler (Ed.), Doing the ethnography of schooling (pp. 48-67). New York: Holt, Rinehart and Winston.

Pillow, W. (2003). Confession, catharsis, or cure? Rethinking the uses of reflexivity as methodological power in qualitative research. International Journal of Qualitative Studies in Education, 16(2), 175-196.

Pillow, W. S. (2015). Reflexivity as interpretation and genealogy in research. Cultural Studies? Critical Methodologies, 15(6), 419-434.

Quinn, M. (2011). Committing (to) ignorance: On method, myth, and pedagogy with Jacques Rancière. In E. Malewski \& N. Jaramillo (Eds.), Epistemologies of ignorance in education (pp. 31-52). Charlotte: Information Age Publishing.

Rancière, J. (2010). On ignorant schoolmasters. In C. Bingham \& G. Biesta (Eds.), Jacques Rancière: Education, truth, emancipation (pp. 1-24). London: Continuum.

Rich, A. (1994). Notes toward a politics of location. In Blood, bread, and poetry: Selected prose 1979-1985. New York: Norton.

Saether, E. (2003). The Oral University. Attitudes to music teaching and learning in the Gambia. Doctoral Dissertation. Lund University. Sweden.

Schippers, H. (2010). Facing the music: Shaping music education from a global perspective. New York: Oxford University Press.

Simpson, A. (2007). On ethnographic refusal: Indigeneity, 'voice' and colonial citizenship. Junctures: The Journal for Thematic Dialogue, 9, 67-80.

Smith, L. T. (1999). Decolonizing research methodologies: Research and Indigenous peoples. London/New York: Zed Books Ltd..

Smith, A. (2013). Unsettling the privilege of self-reflexivity. In F. W. Twine \& B. Gardener (Eds.), Geographies of privilege (pp. 263-280). New York: Routledge.

Thompson, A. (2003). Listening and its asymmetries (Rejoinder). Curriculum Inquiry, 33(1), 79-100.

Trulsson, Y. H., \& Burnard, P. (2016). Insider, outsider or cultures in-between. In P. Burnard, E. Mackinlay, \& K. Powell (Eds.), The Routledge international handbook of intercultural arts research (pp. 115-125). London: Taylor \& Francis.

Van Maanen, J. (1988). Tales of the field: On writing ethnography. Chicago: University of Chicago Press.

Volk, T. M. (1998). Music, education, and multiculturalism. Foundations and principles. Oxford: Oxford University Press.

Webster, J. (2008). Establishing the 'truth' of the matter: Confessional reflexivity as introspection and avowal. Psychology \& Society, 1(1), 65-76.

Westerlund, H., \& Karlsen, S. (2017). Knowledge production beyond local and national blindspots: Remedying professional ocularcentrism of diversity in music teacher education. Action, Criticism \& Theory for Music Education, 16(3), 78-107. 


\begin{abstract}
Alexis Anja Kallio is Senior Lecturer of Music and Research at the Queensland Conservatorium, Griffith University. Her research investigates processes of legitimation in music education policy, practice, and research that structure opportunities for equity and justice. She is the editor of Difference and Division in Music Education (2021, Routledge) and co-editor of Music, Education, and Religion: Intersections and Entanglements (2019, Indiana University Press).
\end{abstract}

Open Access This chapter is licensed under the terms of the Creative Commons Attribution 4.0 International License (http://creativecommons.org/licenses/by/4.0/), which permits use, sharing, adaptation, distribution and reproduction in any medium or format, as long as you give appropriate credit to the original author(s) and the source, provide a link to the Creative Commons license and indicate if changes were made.

The images or other third party material in this chapter are included in the chapter's Creative Commons license, unless indicated otherwise in a credit line to the material. If material is not included in the chapter's Creative Commons license and your intended use is not permitted by statutory regulation or exceeds the permitted use, you will need to obtain permission directly from the copyright holder.

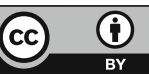

